\title{
ELECTRON MICROSCOPY ON SYMBIOTIC ALGAE IN REEF CORALS
}

$\operatorname{AUTHOR}(\mathrm{S}):$

Kawaguti, Siro

\section{CITATION:}

Kawaguti, Siro. ELECTRON MICROSCOPY ON SYMBIOTIC ALGAE IN REEF CORALS. PUBLICATIONS OF THE SETO MARINE BIOLOGICAL LABORATORY 1973, 20: 779-783

ISSUE DATE:

1973-12-19

URL:

http://hdl.handle.net/2433/175743

RIGHT: 


\title{
ELECTRON MICROSCOPY ON SYMBIOTIC ALGAE IN REEF CORALS ${ }^{\prime)}$
}

\author{
SIRO KAWAGUTI \\ Department of Biology, Faculty of Science, Okayama University \\ Okayama, Japan
}

With 4 Text-figures

Reef corals usually bear a brown color due to the presence of symbiotic zooxanthellae in their tissues. They live in shallow warm waters where they can receive sufficient sunshine for their symbionts. Exceptions are the ahermatypic or non-reef-building corals which have no zooxanthellae and live in shady places or even in deep and cold waters.

A picture of a reef in a shallow lagoon at Kabira, Ishigaki Island in the Ryukyus, (Fig. 1) will show many kinds of Acropora, Montipora, Pocillopora, Porites, Favia, and so on. All of these corals bear a brown color with various modifications in tone and frequently with an additional color such as green, purple, pink or white. This additional color is caused by the presence of different pigments in ectodermal cells.

Among these pigments the green one was studied extensively (1). It is found in the ectodermal cells as small spherical bodies about $0.2 \mu$ in diameter which are contained in vesicles. These bodies are produced in the endoplasmic reticula (3). The pigment is easily dissolved into distilled water and makes a green solution. The solution appears green in reflected light but pink in transmitted light. It shows a beautiful green fluorescence (1). Absorption and fluorescence spectra of this solution are given in Fig. 2. There is a strong absorption band at $320 \mathrm{~m} \mu$. And fluorescent light is composed of $460-500 \mathrm{~m} \mu$. That is, the pigment is responsible for changing the light of short wave length which is harmful for living matter into green light which is useful for the photosynthesis of the zooxanthellae. Short-wave light is abundant in a shallow tropical sea. It is very interesting to know that the host coral provides an effective filter for the symbiont, zooxanthellae, to remove harmful light, and moreover, that it turns harmful light into useful light.

In the daytime many reef corals appear as skeletons covered with soft portions of a brown color frequently ornamented by epidermal pigments. That is, their polyps or tentacles contract in the daytime and expand at night. Some other corals have dayexpanding polyps. The zooxanthellae are found in tissues where a good quantity of

1) Contributions from the Seto Marine Biological Laboratory, No. 575. 


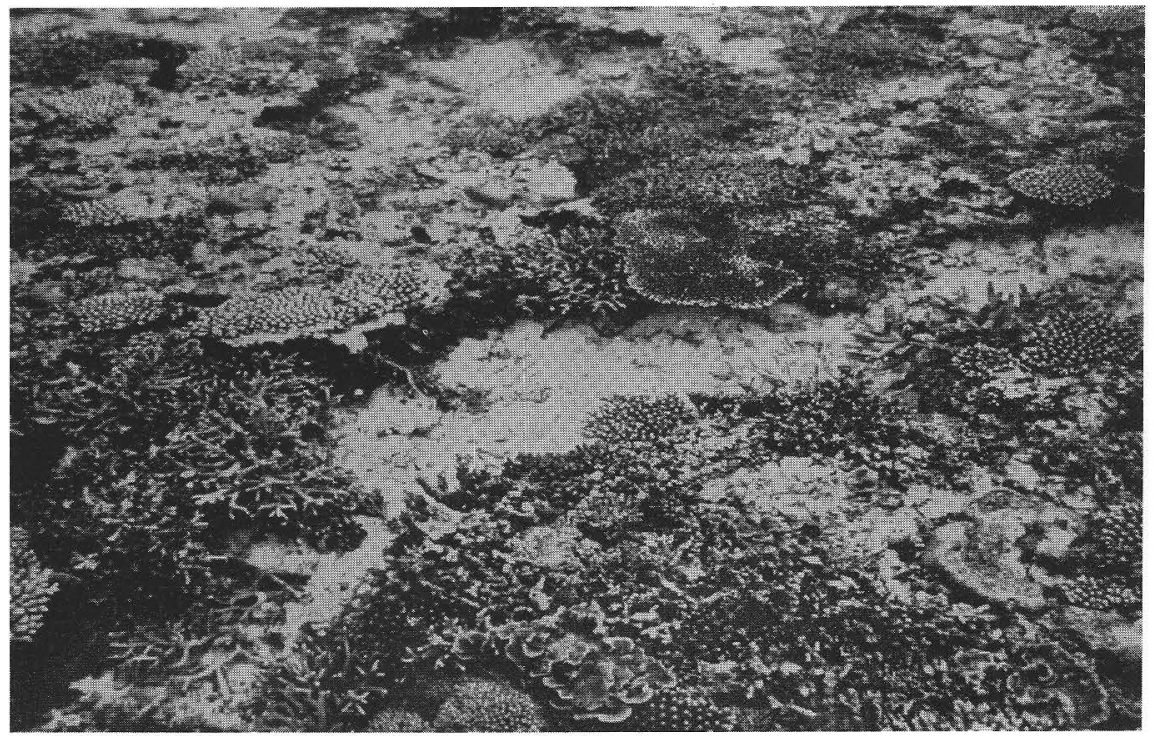

Fig. 1. A view of a reef at Kabira, Ishigaki Island in the Ryukyus. (Printed from a color slide.)

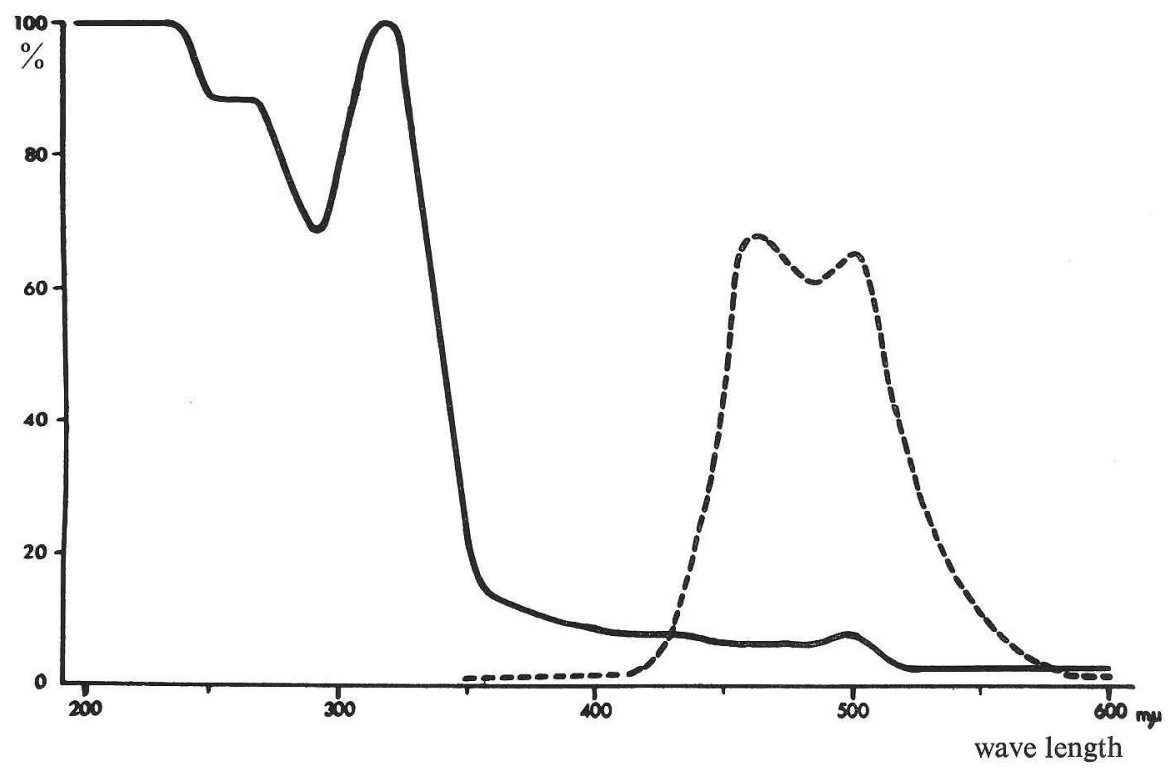

Fig. 2. Absorption (solid line) and fluorescence (broken line) spectra of the green pigment from Lobophyllia robusta. 


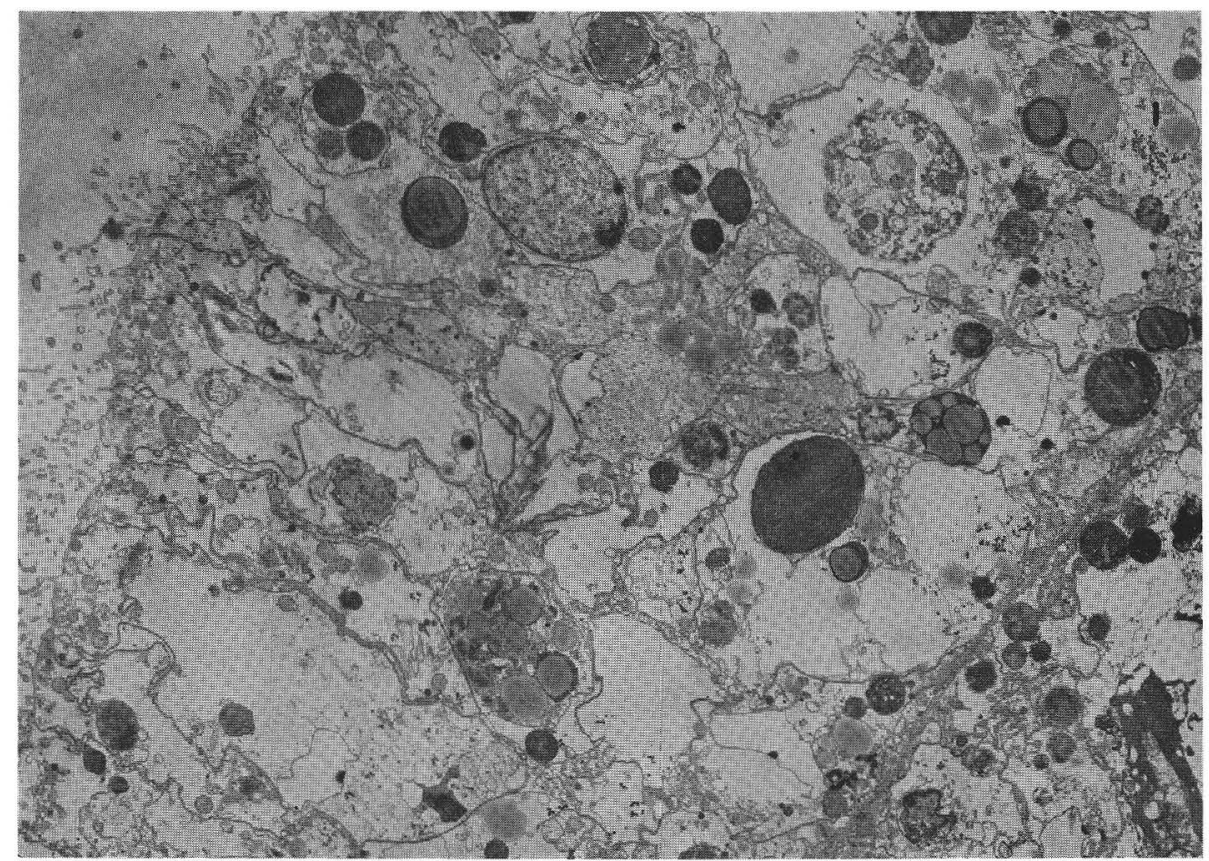

Fig. 3. En electron micrograph of the endoderm of the tentacle of Flabellum japonicum. x 2,400 .

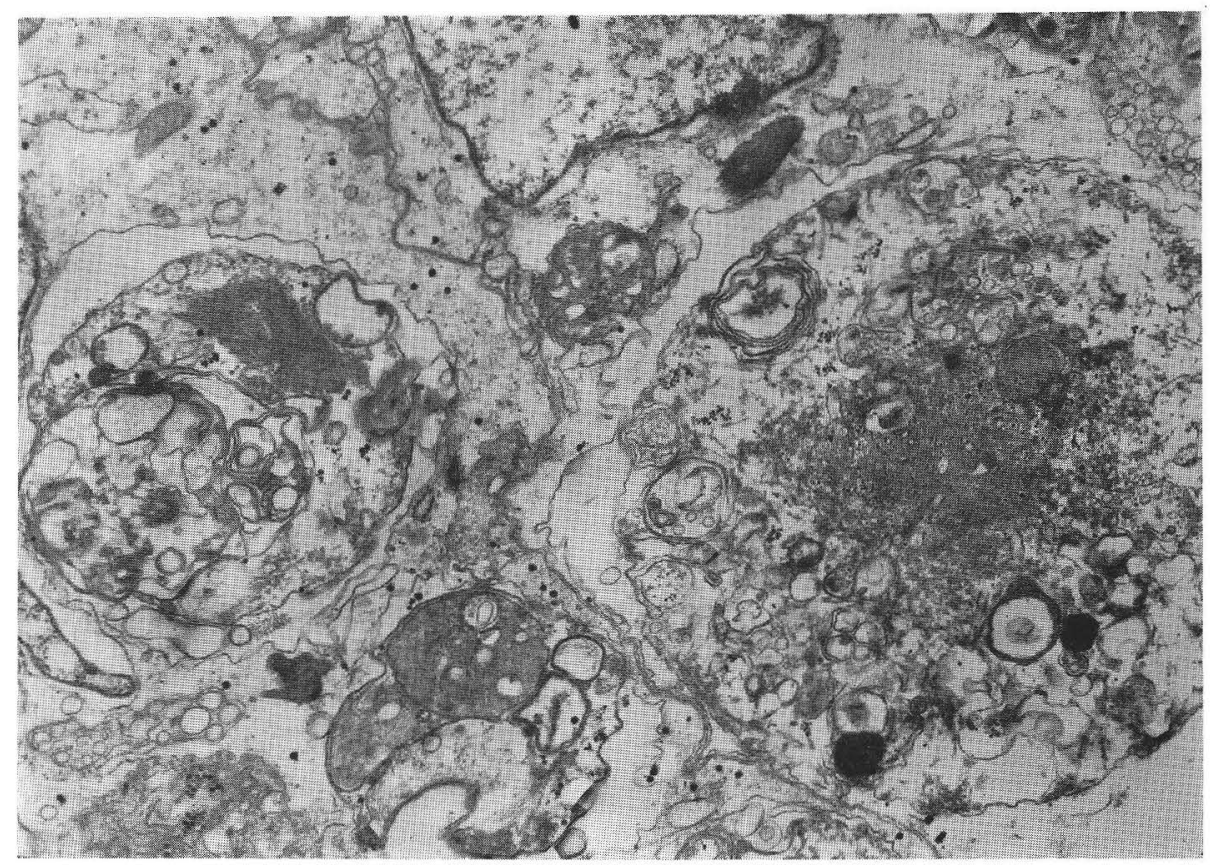

Fig. 4. An enlarged view of the endoderm of Flabellum japonicum showing details of bluegreen algae (A) and bundles of microtubules (B). x 10,000. 
light is received. Night-expanding polyps have only a few or even no zooxanthellae in night-expanding portions. It is astonishing to see that a Faviid coral at night is thickly covered with many transparent tentacles showing quite different features from those in the daytime (6). The distinction between the day-expanding and the nightexpanding types is not clearly fixed. Some night-expanding corals can change into day expanding forms with a gradual increase in zooxanthellae population in that portion (2).

The zooxanthellae are intercellular symbionts in the endoderm of the hermatypic corals. Exceptions are found in staghorn corals in their planulae and apical polyps with six-tentacles. In a symbiotic state in corals the zooxanthellae have no flagella, but when cultured outside they turn into a gymnodinium form with two flagella.

Ahermatypic corals usually bear an orange or a yellow color with some carotenoidlike pigments and are found in shady or deep waters. But, there are some exceptions. Dendrophyllia micranthus bears a velvet black color and lives among other hermatypic corals in shallow water under a bright sunshine. It has no zooxanthellae, but has blue-green algae in the endodermal cells. Flabellum japonicum is found at a depth of more than 100 meters and has a brown color frequently accompanied by fluorescent green on the surface as is usually observed in hermatypic corals.

Fig. 3 is an electron micrograph of part of the endoderm of Flabellum japonicum showing the presence of blue-green algae here and there (5). The endodermal cells have many large vacuoles which contain inclusions of various forms and densities. Some examples are enlarged in Fig. 4 in order to show detailed structures of bluegreen algae which measure from $1 \mu$ to several micra in diameter. The blue-green algae have complicated structures. They frequently show various stages of disintegration in their protoplasm. Some of them may be ingested organisms at various stages in the process of digestion. Another remarkable feature in the endoderm of the tentacle is bundles of microtubules which run in various ways. These bundles of microtubules must be responsible for the expansion and contraction of the endoderm where no muscle fibers are found. Similar bundles of microtubules are reported in the endoderm of the tentacle of Stephanoscyphus racemosus (4).

\section{REFERENCES}

1. Kawaguti, S., 1944. Palao Trop. Biol. Stat. Stud., 2, 617-673.

2. _- 1954. Biol. J. Okayama Univ., 2, 45-50.

3. —, 1966. Ibid., 12, 11-21.

4. Kawagutr, S. and F. Yoshimoto, 1973. Ibid., 16, 47-66.

5. KawaGuti, S., 1973. Ibid. (under press).

6. Yonge, C., 1930. Sci. Rep. Great Barrier Reef Exp., 1, 13-57. 


\section{DISCUSSION}

MACKIE: Have you any quantitative information on the rate of digestion of zooxanthellae in the endoderm and the conditions under which it occurs?

KAWAGUTI: It depends on physiological conditions of the host coral.

Sato: 1) Would you find any definite packing pattern of the well oriented microtubule-the parasitic algae? 2) Any speculative consideration concerning this structure?

KAWAGUTI: 1) There is no definite relation between the bundles of microtubules and the symbiotic algae. 2) Sorry! I am just doing a morphological study.

ARaI, M.: Have you looked at both contracted and relaxed animals with tissues with microtubule bundle?

KAWAGUTI: We observed only in the contracted state.

WERNER: With the reference to the green pigment in ectodermal cells of Lobophyllia, has it any function?

KaWAGUTI: The green fluorescent pigment is functional for a filter of harmful light and it is also a substance to convert harmful light into useful light.

Some additional transparencies showing the tubular structure in Stephanoscyphus cells were projected by $\mathrm{Dr}$. KAWAGUTI. 